NBER WORKING PAPER SERIES

\title{
THE PRODUCTION OF HUMAN CAPITAL AND THE LIFECYCLE OF EARNINGS: VARIATIONS ON A THEME
}

Jacob Mincer

Working Paper No. 4838

\section{NATIONAL BUREAU OF ECONOMIC RESEARCH 1050 Massachusetts Avenue \\ Cambridge, MA 02138 \\ August 1994}

Funding by the National Science Foundation is gratefully acknowledged. The work benefitted from excellent research assistance provided by John Higgins. This paper is part of NBER's research program in Labor Studies. Any opinions expressed are those of the author and not those of the National Bureau of Economic Research.

(c) 1994 by Jacob Mincer. All rights reserved. Short sections of text, not to exceed two paragraphs, may be quoted without explicit permission provided that full credit, including $\odot$ notice, is given to the source. 


\title{
THE PRODUCTION OF HUMAN \\ CAPITAL AND THE LIFECYCLE \\ OF EARNINGS: VARIATIONS \\ ON A THEME
}

\begin{abstract}
After a brief summary of Ben Porath's 1967 model approach, I enquire into the empirical validity and some implications of his insights. Section 2 is an attempt to answer the question: Are the shapes and magnitudes of growth in wage profiles largely attributable to human capital investments? Section 3 tests the proposition that over the working age capacity wages (i.e. wages before netting out investment) decline before observed wages do. Implied timing of labor supply provides the test. The findings shed light on developments in the U.S. labor market in the past several decades. In section 4 some implications are drawn from Ben Porath's model for interpersonal differences and historical changes in life-cycle human capital investments. The positive correlation between schooling and training, predicted by the model is found in crosssections. It also shows up in parallel movements in schooling and training in the 1980 's as the demand for human capital increased. Once again, observed U.S. patterns are highlighted.
\end{abstract}

Jacob Mincer Department of Economics International Affairs Building Columbia University 420 West 118th Street New York, NY 10027 and NBER 


\section{Introduction}

Yoram's 1967 article on the Production of kuman Capital was an important building bloc in the rapidly developing theory of human capital between the late fifties and early seventies. This pioneering work stood the test of time in the following quarter century and is likely to remain significant for future generations of students. Tragically, it has now become a monument to Yoram's memory - much too soon.

Although Yoram spent more time and effort on contributions to the evolving research in the economics of population and the family, his name is most prominently linked to the basics of human capital. He is invariably cited in the myriad of expositions and analyses of human capital, in research papers and in textbooks.

As is well known, the revival of the human capital concept in the late fifties was a response to the appearance of a huge residual in growth accounting, as well as to the findings in U.S. data that the largest component of income inequality is the variance in labor incomes. Human capital analysis promised to correct the inadequacies of the old growth theories and of the functional approach to income distribution. In the latter context, it shifted attention to a major topic in labor economics, that of the determination of the wage structure. In the new analysis, wage 
4

differentials are due to differences in human capital stocks across workers and over time. An important dimension of these differences are age differences in the stocks which are built up over a lifetime. The lifetime accumulation of human capital is the process on which Yoram concentrated by modelling it as an optimal path of human capital investments over the individual's life-cycle. Interestingly, Yoram's approach brings home the realization that human capital's twin responses to findings in growth accounting and in income distribution statistics are basically the same: Aggregate accumulation of human capital is a factor in generating aggregate economic growth, while individual accumulation is the process which generates individual economic growth, a basic micro unit in modern labor economics.

Though familiar to most, a brief summary of Yoram's model should be helpful in introducing the work reported here.

The centerpiece of Yoram's model of optimal capital accumulation is the individual human capital production function, which can. be written:

$$
Q_{t}=f\left(K_{t}, S_{t} * X_{t} ; B\right)
$$

Here $Q_{t}$ is the person's gross investment in human capital in period $t, K_{t}$ is the stock of human capital at the start of $t, s_{t}$ is the 
fraction of time in period $t$ devoted to the production of $Q_{t}$, the gross additions to the stock, $x_{t}$ are purchased goods and services used in the production. B is a parameter added by Becker (1975) in his use of the same production function." B denotes the "limited individual physical and intellectual capacity" which rationalizes Yoram's assumption of decreasing returns to scale.

Koram's model offers a productivity-based explanation of the growth of earnings with working age, as these are proportional to the size of the accumulated stock $K_{t}$. Rational allocations of time for investment requires that most of the investment be undertaken at younger ages. This is because later investments produce returns over a shorter payoff period, so total benefits are smaller. Also, to the extent that investments in human capital are profitable, their postponement reduces the present value of net gains. Finally, later investments could be more costly, if opportunity costs of time devoted to investments increase. However, this would not happen in the special case where productivity in learning grows as fast as productivity in earnings. This latter assumption of "neutrality" is featured in Yoram's model for the sake of simplicity: It keeps the within-period marginal cost curve (MC) fixed over the life cycle.

'Human Capital $(1975$, n. 89, p. 101) Earlier (1bid, n. 22, p. 63) Becker states that his formulation is very similar and much influenced by Yoram's model. Whlle Yoram used the function to analyze the optimal distribution of human capital production over the life cycle, Becker used it to analyze the optimal distribution of total accumulations across persons. 
Given this reasoning, shourd we not expect a rapid accumulation of human capital as early as possible in life? The answer is negative, because attempts to increase investments? within a given period run into diminishing returns: Costs rise with the speed of production. Thus the within period marginal cost curve (as a function of $Q$ ) is upward sloping. Marginal benefits diminish over time mainly because the payoff period is getting shorter, and also because depreciation reduces net gains. Thus the marginal revenue curve (MR) slides downward with advancing age, tracing out a declining pattern of investment over the life cycle. The decline is reinforced if the MC curve shifts to the left with advancing age. Indeed, in a 1970 contribution Yoram tested the neutrality hypothesis empirically concluding that investments decline over the working life faster than would be predicted by the mere downward slide of MR on a fixed MC curve.

While it makes human capital investments decline over the working life, Yoram's optimization process leads to increases in investments during the early stages, before earning activities begin. This is caused by a corner problem: The initial capital stock $\left(K_{0}\right)$ is so small that even an input of all the available time, other resources not being highly substitutable, produces less than the optimal output $Q$. As the stock increases, investors' output increases until an optimum is reached. From this point on time devoted to investment and its volume are likely to decline. The initial period of complete specialization in the production of 
7

human capital is devoted to full-time schooling. It is identified by the absence of earnings, a condition which tends to end before the completion of schooling, and which is more frequently encountered as schooling lengthens.

After this brief summary of Yoram's approach, I enquire into the empirical validity and some implications of his insights. Section 2 is an attempt to answer the question: Are the shapes and magnitudes (of slopes) of wage profiles largely attributable to human capital investments? Section 3 tests the proposition that over the working age capacity wages (i.e. wages before netting out investment) decline before observed wages do. Implied timing of labor supply provides the test. The findings shed light on developments in the U.S. Labor market in the past several decades. In section 4 some implications are drawn from Yoram's model for interpersonal differences and historical changes in life-cycle human capital investments. Once again, observed U.S. patterns are highlighted. 
2. Is the Wage Profile a Result of Human Capital Investments?

Human capital theory elegantly expressed in Yoram's model. explains the ubiquitously observed shape of the wage profile: its upward slope, deceleration, and eventual decline. Since factors other than accumulated human capital are likely to affect the wage profile as well, the significance of Yoram's insights depends on how much of the observed profile can be attributed to human capital investments in a quantitative empirical sense. After completion of schooling these investments consist of formal and informal job training and learning, as well as job mobility involving search on and off the job.

Empirical studies reveal that wage growth within jobs (firms) accounts for the bulk of wage growth over the life cycle ${ }^{2}$, with job mobility accounting for less than $20 \%$ of it, but perhaps as much as 30 f for young workers (working age < 12) in U.S. data. Investments in job search and consequent job mobility contribute to the upward slope and to concavity of the life-cycle wage profile for much the same reasons as those elucidated in Yoram's model. At the simplest level, positive (on average) wage gains from moving are a return on investment in search, and these investments are more frequent at younger ages, as predicted. Mobility gains

2 Mincer and Jovanovic (1981), Bartel and Borjas (1981), Topel and Ward (1992) 
decline also for a typical move as workers age (Mincer, 1986).

Burdett (1978) has shown that s simple job search model which assumes no job training, could explain both the declining frequency and gains to inter-firm mobility over the life cycle. But the magnitude of life-cycle wage growth so achieved can not account for much of the actually observed wage growth as already indicated.

That wage growth is related to in firm training is a finding in many studies, based on a variety of data and periods. viewing this growth as a return on the investment costs produces positive rates of return which vary depending on the data, sample (population group) and period. On average, the range of estimates (Mincer, 1991) exceeds the rate of return to schooling. This is perhaps not surprising since returns on job training investments do not contain consumption (cultural) benefits as school education does for many graduates. In any case, job training investments produce significant wage growth and represent a profitable investment. Also, the incidence and duration of training observably declines with age, which produces concavity in the wage profile, quite in accordance with Yoran's model.

To illustrate: In my study of PSID panel data (1988) I found that annual wage growth of otherwise comparable workers in 1976 jobs was 4.48 greater during the 1968 to 1982 period for those who received training than for those without training in the same year. 
The effect of training on wage growth was 2 to 3 times greater for young workers (working age less than 12) than for older ones. This is due to greater frequency and intensity (in terms of hours per year spent in training) of training of younger workers.

The quantitative question remains: How much of the observed growth in wage profiles is attributable to training investments?

My attempt to answer this question consists of a comparison of indirect estimates of total worker investment costs derived from observed wage profiles with directly observed costs of job training investments. The ratio of the "direct" to the "indirect" estimate of investment costs provides the fraction of observed wage growth that is attributable to job training and learning.

The "indirect" approach dates back to my 1962 work based on Census data for 1959. Costs of job training were estimated from typical (cross-sectional) wage profiles of male workers, classified by education level: Increments of wages over each year of experience in the cross-section ${ }^{3}$ were summed over experience and across education groups and capitalized by internal rates of return." The arithmetic is straightforward even if tedious: The

3 Actual (longitudinal) increments contain in part wage changes due to aggregate growth and cycles, which are not returns on individual investments.

The rates were estimated from pairs of successive education wage profiles. 
annual wage increment

$$
\Delta w_{t}=r \cdot c_{t}
$$

where $r$ is the internal rate and $c_{t}$ the investment cost over the year $t$. The conclusion was that total costs of human capital investments during the working ages were large, almost a half of total costs (including opportunity costs) of school education.

No "direct" estimates of training costs were available at that time. These became feasible for 1976 when a special time-use study of the PSID (Duncan and stafford, 1980) reported job training information. Wage data were available for the same year in the regular PSID panel. Thus for 1976 both "direct" and "indirect" estimates can be constructed and compared.

The "indirect" approach based on wage profiles was implemented on the 1976 data in a much less laborious fashion (Mincer, 1991) than in the 1962 study. The simplification was made possible by the use of a parametric wage function. A semi-log wage function (Mincer, 1974)

$$
\ln w=\alpha z+\tau k_{0} x-\frac{r k_{0}}{2 T} X^{2}+\ln \left(1-k_{0}+\frac{k_{0}}{T} x\right)
$$

contains on the right-hand side a vector of variables $z$ which 
includes years of school education, the experience variable $x$, and the parameters of the a linear investment profile $k_{x}=k_{0}-\left(k_{0} / T\right) \star X$, where $k_{0}$ is the initial fraction of earning capacity devoted to investment, and $T$ the investment period. All the parameters were estimated in a non-linear procedure by $H$. Rosen (1982).

Based on the Rosen estimates Table (1) shows my calculation of inferred investment costs. ${ }^{5}$ with $w$ the average wage in each age bracket, $\mathrm{N}$ the number of workers in it and $k$, the mean investment ratio in the age bracket,

$$
\frac{\sum N w k}{\sum N w}
$$

summed over all brackets yields the average ratio of training investments per hour to wage per hour. The resulting 8.58 ratio was applied to the wage bill in 1976 National Income Accounts and yielded a figure of $\$ 88$ billion of worker post-school investments. Netting out mobility investments as 15: of the above figure leaves the indrect estimate of job training investment costs that would produce the observed (within firms) wage growth at $\$ 75$ billion in 1976.

'For greater detail, see Mincer (1991). Rosen's parameters are estimated on wages of males. My estimates average male and Female investment ratios, with the latter assumed to be a half of the former, and applied to the wage bill of females which was about 407 of the total in 1976. 
All that is needed for the "direct" estimate of job training investment costs is the time spent in training per period and the period opportunity cost of that training. The 1976 PSID Time ise Survey is the only such survey of time allocation on the job during a week's period. The data are shown in Table (2). The calculation is simple: It is the product of columns 1 through 4 summed over all ages: Total costs per week

$$
T C=\sum w \cdot h \cdot N_{t}
$$

where $w$ is the wage foregone, $h$ hours of training per week, ${ }^{6}$ and $N_{t}$ the number of workers receiving training during the week. So estimated, total annual costs of job training amounted to about $\$ 56$ bitlion in 1976 .

One check on this order of magnitude is available from a survey of companies published in Training Magazine. The survey reported expenditures on formal training of about $\$ 40$ billion in 1987. The time spent in formal training was about a week per trainee. This does not include time spent in informal training or learning on the job which is the preponderant manner of training in the U.S. Indeed, the PSID Time Use Survey suggests an average of about five weeks ( 200 hours) of training per year, so if the time

6 The Time Use Survey lists separately training time without production and d time with production ongoing. Only a third of the latter was (conservatively) estimated as training time. The two components are summed in col. 2 . 
spent in all forms of training in 1987 is the same as in 1976 , the report from firms would suggest a figure of about 200 billion of 1987 dollars in 1987. Projecting the 55.7 billion to 1987 (assuming the same ratio of training expenditures to the wage bill) yields about $\$ 150$ billion in 1987 . Apparently the training ratio increased by 1987,7 so the estimates based on the two entirely different and independent surveys are not very different.

The "indirect" estimates of job training expenditures based on wage profiles and the "direct" ones using the PSID Time Use survey provide the best comparison as they were taken in the same year. since growth in the wage profile over the working age is likely to include factors other than job training it is reasonable to find the "Indirect" estimate to be larger ( 75 billion) than the direct estimate (56 billion). This suggests that roughly $75 \%$ of the (cross-sectionally) observed intra-firm wage growth over the lifecycle is attributable to job training or learning, while $25 \%$ is likely to contain factors which produce an upward sloping wage profile other than human capital investments. ${ }^{\circ}$ This is rather persuasive evidence for the validity or primacy of the human

7 see section 4 below.

A series of rough calculations suggests that a generous margin of error could lower this ratio to $65 \%$ or raise it to $85 \%$. The other models which posit an upward slope of the wage profile, aside from job training, include employer schemes to economize on costs of monitoring (Lazear), on costs of turnover (Salop and Salop) and wage outcomes of job matching (Jovanovic). No empirical evidence exists on the quantitative empirical importance of these undoubtedly plausible models. 
capital interpretation of the wage profile, as proposed by Yoram and his followers.

3. Observed Earnings, Capacity Earnings, and Hours of Work Over the Life cycle.

While the neutrality hypothesis is easily relaxed to produce more realistic implications, another simplifying assumption in Yoram's model is the two-way allocation of time between learning and earning. Time spent in consumption or leisure is not considered, or assumed fixed. Because of the difficulty in analyzing 3-way choices, models have first considered either the labor-leisure choice (as in Ghez and Becker, 1975) or the laborhuman capital investment choice (as in Ben-Porath). Blinder and Weiss (1976) and Heckman (1976) broadened the analysis to three-way choices. The results add complexity to the analysis of life-cycle patterns especially in terms of effects of production-function specifications and of consequences of differences in initial conditions. Although the extensions represent improvement, Heckman concludes that the Ben-Porath model survives the complexities rather well.

Even without a simultaneous analysis of three-way choices, the observed life-cycle patterns of hours of work may be helpful in testing a distinction that is important in Yoram's analysis of the 
life-cycle wage profile. The distinction is between capacity wages and net wages. The latter are wages from which investment (training or learning) costs are netted out, so these are basically what we observe, while capacity wages are not observable without a specified or visible investment profile.

One of the distinctions between the two wage profiles is the timing of peaks: because depreciation eventually outstrips declining gross investment, net investment becomes negative and capacity wages begin to decline. However net or observed wages continue to rise for a while reaching a peak later in life than capacity wages do. The proof is simple: Let $w_{t}$ be observed wages at working age $t, w_{c t}$ capacity wages, and $c_{t}$ investment component of capacity wages:

$$
w_{c t}=W_{t}+c_{t}
$$

Peak of $w_{c t}$ is reached when

$$
\frac{d w_{c t}}{d t}=0=\frac{d w_{t}}{d t}+\frac{d c_{t}}{d t}
$$

At the peak of $w_{c}$

$$
\frac{d w_{t}}{d t}>0, \text { since, } \frac{d c_{t}}{d t}<0 \text {. }
$$


that is, $w_{t}$ is still rising.

Life-cycle labor supply models as in Becker and Ghez (1975). predict a positive relation between wages and hours over the life cycle $e^{\circ}$ as intertemporal substitution dominates the wealth effects. The latter are zero or negligible as wealth expectations are assumed basically unchanged after completion of schooling. Since the price of time is properly measured by capacity wages rather than by observed wages, the peak of hours of work would occur at the same time as the peak in capacity wages. We can therefore, empirically test for the lag between peaks of capacity and observed wages as well as measure its size. The magnitude of the lag between the peaks of capacity and observed wages can be gauged from the simplified quadratic wage function shown in (2):

$$
\ln w_{c}: a z+r k_{0}-\frac{r k_{o}}{2 T} X^{2}
$$

Here as before, $z$ includes years of schooling and other variables, $r$ is the rate of return to post-school investments, $x$ is years of labor-market experience, and the linear investment profile in $x$ is $k_{n}=k_{0}-\left(k_{0} / T\right) \star X ; k_{0}$ is the initial fraction of earning capacity devoted to net post-school investment, and $T$ the positive net investment period. Thus the peak of $w_{c}$ occurs at $x=T$.

9 They also predict a lag between wages and hours, but for different reasons. See discussion below in note 12 . 
For observed earning, add $\ln \left(1-k_{x}{ }^{*}\right)$ to $(2 a)$, as $w=\left(1-k_{x}{ }^{*} \star^{*} w_{c}\right.$. Approximating $-k_{x}{ }^{*}=l n\left(1-k_{x}{ }^{*}\right)$. Here $k_{x}{ }^{*}$ is the gross investment ratio.

$$
\ln w-\alpha z \cdot r k_{0} x-\frac{r k_{o}}{2 T} x^{2} \cdot k_{x}
$$

Assuming a fixed depreciation rate, the decline in $k_{x}{ }^{*}$ is the same as in $k_{x}$, that is, $\left(k_{0} / T\right)$ in the linear case. Hence, the peak of observed wages occurs when

$$
\frac{\partial \ln w}{\partial x}=0=r k_{0}-\frac{r k_{0}}{T} x+\frac{k_{0}}{T}
$$

Solving for $x, x_{p}$ (time of peak observed wages) $=T+(1 / r)$. Thus, if the human capital interpretation of the lag is correct, with an approximately linear profile of investment ratios the lag would roughly equal the inverse of the rate of return to training, a range covering a bit more or less than a decade as the rate fluctuated over time.

The assumption of relatively fixed wealth expectations in the life-cycle model of labor supply applies more readily to cohorts than to cross-sections. With secularly growing wealth, progressively older cohorts would show longer hours of work corresponding to lesser wealth, biasing the peak of hours forward in cross-sections. On the other hand, secular growth in wages shifts the peak of wages and of hours toward older ages within 
cohorts. Hours shift in tandem, because the price of time changes regardless of whether the change is due to human capital or to overall economic growth. The shift in cohort peaks can also be gauged roughly with wage function (2); incorporating a g percent growth term:

$$
\ln w_{c}=a z+r k_{0} X-\frac{r k_{o}}{2 T} x^{2}+g x
$$

Now

$$
\begin{gathered}
\frac{\partial \ln w_{c}}{\partial X}=r k_{0}-\frac{r k_{0}}{T} X+g=0, \\
\text { so } x_{p}=T+T \cdot \frac{g}{r k_{0}}, \text { and } \frac{d X_{p}}{d g}=\frac{T}{r k_{0}}
\end{gathered}
$$

Using the parameters estimated by $H$. Rosen for $1976 \mathrm{~T}=26, \quad r=0.12$, and $k_{a}=0.32$, an increased rate of growth by 1 would shift the peak of $w_{c}$ by close to 7 years. If $g$ declined by 2 percent points, as it did for the less skilled labor force groups in the U.S. in the past two decades compared to earlier periods, peak wages and peak hours would have shifted between a decade or two. Thus the more recent cohorts would show declines in wages and in hours that are much earlier than in the older cohorts.

The existence of lags, their magnitudes, and shifts over time during the years 1964 to 1991 are shown in Figures (1-3) and Tables $(3,4)$. 
Data on which the Tables are based come from annual cPs surveys in the years 1964 to 1991 . They are restricted to males of working ages. Annual earnings and annual hours are far better measured in the CPS than in the 1960 census used in the pioneering work of Becker and Ghez (1975). First, weeks and usual hours per week refer to the same calendar year, and secondly, we imposed a number of restrictions to eliminate outliers in hours, earnings, and earnings per hour, including a blanket exclusion of the upper and lower 3 percentiles of workers. We then calculated average wages and average hours for each year of experience in five education groups: Years of schooling $<12,12,13-15,16,>16$. The over 200 means were computed for each calendar year in cells which on average exceeded 100 workers. To minimize reporting and sampling errors, we used 3-year centered moving averages to get the experience profiles of hourly wages (CPI deflated) and annual hours. The annual cross-sections make it possible to construct 26 cross-section profiles for each education level, as well as synthetic cohort data in wich the same cohort, defined by education and age, is one year older in the next calendar year. Becker and Ghez used the 1960 Census cross-section, "because information on a single cohort at different ages is lacking" (p. 83). With our data we can explore the relation between hours and wages in the synthetic cohorts as well as in cross-sections. In addition, we used three different definitions of labor input: (1) Annual hours for workers employed some time during the year (2) Annual hours including zeros for those not employed, and (3) 
Percent of Population employed in each cell. Very similar patterns hold across all three definitions. (For the sake of brevity we deleted the employment-population ratio and the "some college" group from the presentation here.)

The cohort graphs and Tables display 6 cohorts: the oldest was 55 years of age in 1964 , followed by ages $50,45,40,35,30$. The cross-sections start with calendar years 1965; again followed by five-year intervals down to 1990. As expected, peaks of hours precede peaks of wages in every cohort. It is also true in most but not all cross-sections where the peaks are generally more ambiguous and erratic. ${ }^{10}$ Remarkably the average duration of lag between peak wages and peak hours runs from 6 to 10 years in cohorts but covers a wider range in cross-sections ( 1 to 16 years). Note that the size of the average lag is a reasonable order of magnitude for the inverse of the rate of return!

Note also, that the rate of growth of average real hourly earnings declined from close to $g=2 \%$ per annum before 1973 to little more than $0.5 \%$ afterwards (Bound and Johnson). This decline held mainly for the 70 of of the less skilled (education $<=12$ ) workforce, less so or not at all for the better educated and

to The flatness of the profiles makes the choice of peaks ambiquous. We chose the oldest peaks in all graphs. The cohort peaks are less problematic. 
skilled workers. ${ }^{11}$ As predicted, peaks of wages decline by about a decade and a half from the oldest to the youngest cohorts of workers with high school or less. Small or no declines are observed for the more educated workers. Hours fall in all groups but much more in the two less educated groups (about two decades compared to less than a decade among college educated).

The shift in peak wages and hours over the historical period is not noticeable in the cross-section profiles, although as already mentioned, the lag between peak wages and peak hours is usually preserved.

The cohort findings are more informative showing the implications of the decline in the rate of growth of wages in addition to the lag of peaks of wages and hours.

Interestingly, while the cross-section profiles show no age bias in the changing rates of growth of wages, the cohorts show declines in hours of work at progressively younger ages. These declines are due to the secular declines in rates of growth of real wages, themselves a result of declines in productivity-based demand for less-skilled labor. It is this skill-bias that translates into an apparent age-bias, despite its absence in the series of crosssections.

11 For the less skilled the growth rate actually became negative after 1973. 
To recapitulate: The proposition that capacity wages reach a peak before observed wages do can be tested on the basis of the life-cycle labor supply theory, since capacity wages measure the relevant cost of time. Both cohorts and cross-section profiles document the lag, and its duration appears to be of the order of magnitude predicted by the inverse of the rate of return to postschool investments. Both peaks of wages and of hours shift towards younger ages in consequence of the decline in the rate of growth of wages of workers with education of high school or less. The magnitude of shift in wages and hours is again consistent with observed parameters of a simple human capital wage function. These shifts are not detectable in cross-sections, suggesting.that it was the skill-biased change in demand for labor rather than an age-bias which created the decline in hours (and participation) at progressively younger ages during the last two decades in the U.S.

Incidentally, the distinction between observed and capacity wages suggests that the usual estimates of the intertemporal substitution over the life cycle are severely understated since they are incorrectly based on observed and not capacity wages. The understatement occurs because the relevant capacity wage profile is flatter on the upswing than the observed profile. The difference between the two profiles diminishes as the investment ratio diminishes over time. Moreover, in the interval between the two peaks the correlation between capacity and observed wages is 
negative, further reducing the elasticity. ${ }^{12}$

4. Schooling, Ability, and Job Training

Although Yoram's model addresses itself to intertemporal differences in human capital investments over the life-cycle, it has clear implications for interpersonal differences. ${ }^{13}$ At any life-cycle stage the marginal cost of producing human capital is lower for persons with greater learning ability. ${ }^{14}$ On the benefit

12 Becker and Ghez show estimates of wage elasticities for males by education level in the 1960 Census in their 1975 study (Table 3.5). These elasticities appear to be smaller the higher the education level ( 3 levels were used: school, high school, and college graduates). This is consistent with the larger discrepancy between observed and capacity wages at higher levels of schooling, as job training investments are correlated with school education, a matter discussed in the next section here.

We should note that Becker and Ghez were the first to show (with the cross-section data) that hours of work decline before observed wages do in the life-cycle. The size of the lag ranged from 5 to 30 years, for white men in 1959, a variation that is probably affected by measurement error.

The existence of the lag is interpreted by Becker and Ghez as an effect of positive interest rates and of time preference which induce workers to shift work hours toward earlier ages. Even if theoretically sound this hypothesis does not yield predictions of orders of magnitude. If correct it would lengthen the size of the lag observed on account of the human capital interpretation provided here. The evidence on such an additional effect is not detected in our data.

${ }^{13}$ These are put in a demand-supply framework in Becker (1975) .

14 In an illustrative Cobb-Douglas function, more output $Q$ is produced with the same inputs ( $S$ and $K$ ) when the ability parameter $b$ is larger:

$$
Q_{t}=\beta\left(S_{t}, K_{t}\right)^{b}
$$


side, marginal revenue is greater the easier the access to financing or the lower the interest rate on funds faced by parents, students, and trainees. ${ }^{15}$ so persons with greater ability to learn and with lesser costs of funds and greater time preference for the future invest more in human capital in all periods. since more schooled individuals are likely to be more able and/or to face lower discount rates, they are also more likely to invest more in job training. In the Ben-Porath diagram, for them the higher Marginal Revenue curve slides down on a lower Marginal cost curve, tracing out a series of larger quantities of additions to human capital $Q$.

The empirical implications of this reasoning are (1) Persons with more schooling tend to invest more in job training (2) Persons who engage more than others in job training in early periods tend to do so also in later periods (3) Persons with greater ability or better schooling engage in more job training, even with the same (nominal) schooling attainment.

The first implication, a positive correlation between schooling and job training has been observed in numerous studies

15

$$
M R=\frac{a}{r+\delta} \cdot F
$$

where alpha is the return on a unit of human capital, $r$ the interest rate, delta is the depreciation, and $F$ a less-than-unity correction factor for the finite payoff period. 
starting with Lillard and Tan in 1986. In my study (1988, 1993) of PSID data reported in 1976, 1978 and in 1985 I found that years of schooling significantly affected the incidence and duration of job training, holding constant experience. levels, marital and union status (Mincer, 1993, Table 8.2). I also found that training in 1985 was persistent for those who trained in 1978 and/or in 1976, even though they were not in the same firm, holding years of schooling constant (Table 8.4, ibid).

The fact that ability, as measured by test scores, is related to schooling attainment, as cause or effect, has long been observed. Evidence of ability as an input to schooling is shown for example by the observation that standardized scores on verbal and numerical tests in the last year of high school strongly predict future educational attainment. ${ }^{16}$ since these ability scores have also been shown to increase with years of schooling, they may also represent a human capital output, or a measure of school quality in addition to being a student characteristic. In any case, higher scores at given levels of schooling represent higher levels of human capital, and should lead to larger investments in training. This hypothesis is confirmed in recent NLs data in a current study by Bartel and sicherman (1993).

Ability test scores obtained in 1980 for members of the NLS (1993).

${ }^{16}$ The most recent study is by Murnane, Willett, and Levy 
Youth panel were used by Bartel and Sicherman ${ }^{17}$ arong a number of variables as determinants of the incidence of job training, especially company training in the years 1980 to 1990 . The effects of numerical and mechanical aptitude were significant, after standardizing for a large number of variables. That is to say, at the same level of experience and schooling, more training is reported by young men with higher aptitude scores. Conversely, at the same aptitude levels, young men with more schooling receive more training. These effects of aptitudes and of schooling are probably understated as a number of additional variables reflecting correlated human capital levels are included as independent variables in their regressions. These are: length of tenure, marital status, firm size, industry, location, and sectoral productivity growth.

Just as individual differences in benefits and costs produce individual differences in schooling and training, so changes in benefits and costs, that is in their profitability, should affect human capital investments in their various forms or life-cycle stages over historical time. Yoram's analysis distinguished schooling from job training only as a sequence in the life cycle, the first a full-time the second a part time activity. Otherwise the human capital produced in each is homogenous. Therefore, if we

17 I am grateful to Bartel and sicherman for permission to cite the (preliminary) findings. It is interesting to note that as the test scores were not available to employers, their provision of training and the higher wages resulting from it can not be attributed to a "screen". 
ask whether increases in demand for human capital induce increases in its supply at all stages of the life cycle, the answer ought to be positive.

As is well known, the profitability of education, measured by rates of return grew strongly in the U.S. in the 1980's. There is accumulating evidence that the growth of demand for human capital or of "skill-biased" demand for labor was the moving force, while the supply of educated workers grew rather slowly in response. Thus between 1979 and 1988 the education "wage premium", as measured by the percent differential between wages of college and high school graduates ${ }^{18}$ with about a decade of work experience, more than doubled; enroliments of 18-24 year olds as a proportion of High School graduates grew from 31 to $37 \%$ (Clotfelder, 1991; Table 2.7). This growth appears to be a response to the increasing wage premium, as I find that the latter variable is highly significant in affecting enrollments, even after tuition, family income, and unemployment are accounted for. ${ }^{19}$

Do we find corresponding increases in profitability and in volumes of job training?

10 This measure differs from a properly calculated rate of return, as it omits direct costs of schooling. This omission inflates the measure somewhat, but does not affect its course over time.

19 Based on current, unpublished research. 
Several pieces of evidence provide an affirmative answer: (1) In my 1991 study I correlated annual education "wage premia" with slopes of experience-wage profiles (Mincer, 1991, 1993, Table 13.5). The regression coefficient on educational profitability is highly significant and equal to or greater than unity, holding the age distribution constant. A similar finding was reported by Allen (1993) who correlated educational wage differentials within twodigit industries with slopes of wage functions estimated in each cross-section and over time (over the $1980^{\prime} \mathrm{s}$ ). The dependent variable (experience slope) is basically a product $r \star k_{0}$, where $I$ is the rate of return to postschool investments (largely job training and learning) and $k_{0}$ the initial ratio of investment to earning capacity. The first is a measure of profitability, the second of volume. We expect the latter to increase in response to an increase in the former, so the product would certainly increase. That volumes of training increased is suggested by a comparison of data in two recent USDOL Reports carried out by the BLS in 1983 and 1991 on special CPS surveys. ${ }^{20}$ In the 1991 survey training was reported by 41 of workers, up from 35t in 1983. Moreover, the average duration of training, at least in the formal company programs increased from 8 to over 12 weeks. Training activities increased in all age groups and all schooling groups, but not equally: Worker groups which already had high levels of schooling and of training increased their training most. Thus most of the

20 The findings are reported in Training to be competitive, published by ETS, Princeton, 1993. 
expansion of training is observed among workers with post-secondary education and in age groups 30-50, where repeated training also increased.

Whether this skill-bias in the production of new human capital corresponds to the skill bias in the market demand for labor, both reflecting effects of new technologies, is a question that deserves exploration.

Aside from the skill-bias phenomenon, the basic features of interpersonal differences and of historical change are illuminated Within Yoram's model of homogeneous human capital. Viewing the products of schooling and training, as heterogeneou's forms of human capital would lead to similar predictions if schooling and training tend to be complementary rather that substitutable: An increase in demand for schooling would also raise the demand for training. However a richer insight into the various non-neutralities would be gained by the implication that a higher marginal product (efficiency) of training requires more or better schooling (and ability). These issues are outside of Yoram's model. The limits were intentional, to provide an all-the-more powerful focus in a landmark advance in human capital theory. 
Summary: Yoram Ben-Porath's Contribution to Human Capital Theory

The subject of individual growth and aging has been studied in biology, medicine, psychology, and anthropology for a long time. The economic aspects of individual development began to receive treatment only in the past few decades with the emergence of human capital theory. Individual economic development is a basic unit of analysis both in modern theories of aggregate economic growth and in labor economics. A succinct model of individual economic growth was formulated by Yoram Ben-Porath and published in 1967. In it the lifetime accumulation of human capital is viewed as an optimal path of human capital investments over the life cycle. Two basic ideas (inputs) drive the production model: one, that it takes human capital to produce more of it, and two that it is the diversion of that ultimate resource, time, from other uses that is the other major input in the production of human capital. In turn, the age distribution of investment is optimized by equating its marginal benefits and costs within each period. When we think of the process of human capital accumulation as the transmission and growth of knowledge and of skilis, we realize the full significance of Yoram's insight in pinpointing the economic mechanism at the individual level.

Although the ideas expressed by Yoram were shared by others at the time, his model provides the most succinct, rigorous, and fruitful formulation. Its fruitfulness became almost immediately 
apparent in the further developments of human capital theory: As Becker states in the second edition of his Human Capital (1975), his formulation and use of the human capital production function was much influenced by Yoran's model. While Yoram used the agespecific costs and benefits to analyze the optimal age distribution of human capital accumulations, Becker used these same costs and benefits in a supply-demand framework to analyze the optimal distribution of completed accumulations across persons.

The qualitative implications of Yoram's model for the ageearnings profile were translated into an econometric tool in my own development of the earnings function in 1974. The efficacy of this tool, provides a further boost to the general realization of the potential power of Yoram's model.

Yoram's model offers a productivity-based explanation of the growth of earnings with working age. Formal or informal on-the-job training is the major productivity building investment, after completion of schooling. Accepting Yoram's implication of the nearly linear decline over the working age in the fraction of time devoted to such investments, the observed human capital earnings function can be empirically analyzed to reveal the investment profile and the rates of return on the investment. This is on the assumption that the wage profile is indeed a consequence of job training.

With the appearance of direct information on job training activities, their cost and their wage consequences, Yoram's hypothesis is tested more directly in my recent work described in 
section 2 of this paper. The conclusion that post-school human capital investment is the primary factor underlying the slope of the wage profile is confirmed in U.S. data.

The distinction Yoram introduced between capacity and observed wages is important in deriving the earnings function, but it also turns out to be quite useful in providing insights into intertemporal changes in hours of work, especially across recent cohorts in the U.S., as $I$ show in section 3 .

Yoram's model, which addresses inter-temporal differences over the life-cycle, has also clear implications for interpersonal differences in human capital investments. Among them are the following observed phenomena:

(1) Persons with more schooling tend to invest in more job training

(2) Persons significantly engaged in training in one period are Iikely to do so again in future periods or employments

(3) Persons with greater ability or better schooling tend to engage in job training more than others with the same (nominal) schooling.

(4) When the demand for human capital increases, both the profitability of schooling and of job training increases - at least in the short run. Consequently school enrollment and job training incidence increase.

All of these implications are empirically confirmed in section 
4 of this paper.

The positive correlation between schooling and training across persons and over time is implied by the homogeneity of human capital assumed by Yoram. As all fruitful landmarks are, Yoram's model is a starting point. The deliberately imposed limitations in 1t, such as the homogeneity of human capital, the neutrality hypothesis, and the two-way allocation of time between learning and earning, are all invitations to further probing when the restrictions are relaxed. But, we owe it to Yoram's intuition that much is accomplished within the restrictions while relaxing them invites further insights. 


\section{Reterences}

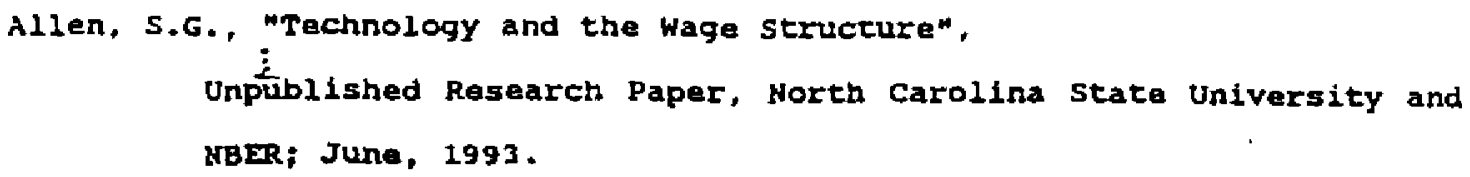

Bartel,A. and G. Borjas, "Wage Growth and Job Turnover", in S. Rosen, ed. studies in Labor Sarkers, U. of chicago Press, 1981

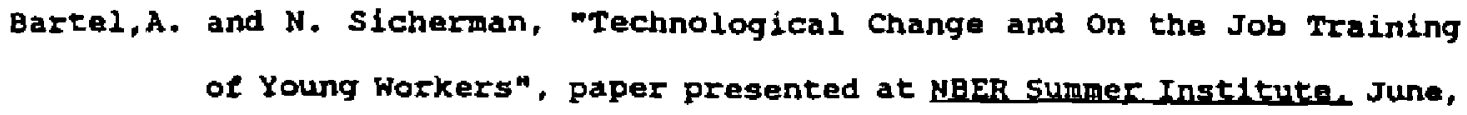
of Young workers", paper presented at NBER Summer Instltute, June, 1993.

Becker, G.S., Human Capital, 2nd ed, chicago University Press, 1975.

Becker, G.S. and G. Ghez, The Allocation of Time and Goods over the Life sycle, Columbia U. Press for NBER, 1975.

Ben-Porath, Y., "The Production of Human Capital over $T$ ime", in $w$. $L$. Hansen, ed.. Educaclon. Income and Human capital, Columbia University Press for NBER, 1970.

Ben-Porath, Y., "The Production of human Capital and the Life-cycle of Earnings", Journal of Political Economy, August 1967. 
Blinder, A. and $Y$. Weiss, "Human Capital and Labor Supply: A Symthesis", Iournal of Polftical Econony, June 1976.

Bound, J. and G. Johnson, "Changes in the structure of Wages During the 1980 '" , Amertcan Economic Reyley, June 1992.

$\dot{2}$

Burdett, X." "A Theory of Employee Job Search and Qult Rates", American Rconomic Reylew, March, 1978 .

Duncan, G. and F. Stafford, "The Use of Tlme and Technology by Households in the U.S.". Regearch in Labor Economics, vol.3, 1980.

Educational Testing Service, "Training to be competitive" Rollcy Report, Princeton, 1993.

Heckman, J., "a Llte cycle Hodel of Earnings, Learning, and consumption", Journal of Politheal Economy, Part 2, August 1976.

Jovanovic, B., "Job Matching and the Theory of Turnover", Journal of Polltical economy, october 1979.

Lazear, E., "Why is there Mandatory Retirement?", Journal of Political Economy, September 1979 .

L12ard, L. and H.Tan, Private Sector Training, Rand Report, March 1986. 
Mincer, J., "on the Job Training". Journal of Political Economy, Part 2 , October 1962 .

Mincer, J., Schooling, Expertence, and Earnings, Columbia U. Press, 1974.

Mincer, I., "Wage Changes in Job Changes", Research in Labor Economles, vol. BA, 1986.

Mincer, J., "Job Training, Wage Growth, and Labor Turnover", 1988 NBER Horking Paper 2680; Published in J. M1neer, studias in Human Capital, E. Elgar 1993.

Hincer, J., "Job Training; Costs, Returns, and Wage Profiles", in Market Failure in Job Training?, D. Stern and J. H. M. Ritzen, eds., Springer Verlag, 1991.

Mincer, J., MHuman Capital, Technology, and the Wage Structure", NBER WP 3581. Published in J. Mincer, Studies in Human Capital, E. Elgat. 1993.

Murnane, J. R., Willett, J.B. and F. Levy. "The Growing Importance of Cognitive skills in wage Determination", Research Paper, March 1993. 
Rosen, H.. "Taxation and on the Job Training Decisions", Reyler, of Economies and statigtlag. August 1982 .

Salop, J. and s. Salop, "Self Selection and Turnover in the Labor Market", quatterly Journal of Economtes, November 1376 .

Topel, R. and M. Ward, "Job Mobllity and the Careers of Young Men", puarterly Journal of Economics, May 1992. 
Table 1

Calculation of 1976 Woricer OJI Inverments

Derived from Wage Function

\begin{tabular}{|c|c|c|c|c|c|c|}
\hline Age & Mean Age & k & $\mathrm{Nr}$ & $N=k$ & & \\
\hline$<15$ & 22 & .23 & 74 & 17.0 & & \\
\hline $25-34$ & 30 & .15 & 126 & 18.9 & & \\
\hline $35-44$ & 40 & .05 & 102 & 5.1 & & \\
\hline $45+$ & & 0 & 182 & 0 & Ratio & Dollers \\
\hline \multicolumn{3}{|c|}{ Total } & 484 & 41.0 & $8.5 \%$ & 588.4 brilion \\
\hline
\end{tabular}

Sources: $k$ estimated Irom Rosen (1982); $N$ and $w$ from Table 2.

Table 2

Worker Opportunity Costs of Job Training, 1976

\begin{tabular}{|c|c|c|c|c|c|}
\hline Age & $\begin{array}{c}\text { Eourly } \\
\text { Wage } \\
\text { (WJ } \\
\text { (I) }\end{array}$ & $\begin{array}{l}\text { Elours of } \\
\text { Traioing per } \\
\text { Week (h) } \\
\text { (2) }\end{array}$ & $\begin{array}{l}\text { Percent } \\
\text { with } \\
\text { Training } \\
\text { (p) } \\
\text { (J) }\end{array}$ & $\begin{array}{l}\text { Number } \\
\text { of } \\
\text { Employee } \\
\text { s (N- } \\
\text { minlions) } \\
\text { (4) }\end{array}$ & $\begin{array}{l}\text { Costs (Smin) } \\
\text { per Week } \\
\text { (T/pN) } \\
\text { (5) }\end{array}$ \\
\hline$<25$ & 53.7 & 6.4 & 76 & 20.0 & 360 \\
\hline $25-34$ & 5.6 & 4.3 & 72 & 22.5 & 390 \\
\hline $35-44$ & 6.2 & 3.8 & 58 & 16.5 & 275 \\
\hline $45-54$ & 6.7 & 2.2 & 48 & 16.1 & 114. \\
\hline \multirow[t]{2}{*}{$55-64$} & 6.3 & 1.1 & 29 & 10.9 & 22 \\
\hline & & & & $\begin{array}{l}\text { Total } \\
\text { Cost }\end{array}$ & \$I, 121 \\
\hline
\end{tabular}

Soures: Col. (1), (2), and (3) from Duncan and Stafford, 1980

Training hours in col. (3) calculated as sum of separate hours in training and one-third of hours spent jointly in training and production.

Col. (4) from Employment and Eamings, BLS, 1976.

Col. (5) is the product of col. (1) through (4). 
TABLE 3: COHORTS

Peak Ages in Wages and Hours

\begin{tabular}{|c|c|c|c|c|c|c|c|c|c|c|c|c|}
\hline \multirow[b]{2}{*}{ Educ } & \multicolumn{4}{|c|}{ Wages } & \multicolumn{4}{|c|}{ Hours of Enployed } & \multicolumn{4}{|c|}{ Lag } \\
\hline & $<22$ & 22 & 16 & $>26$ & $<12$ & 12 & 16 & $>16$ & $<12$ & 12 & 16 & $>16$ \\
\hline AGE & \multicolumn{12}{|c|}{ cohorts dellneated by age in 1964.} \\
\hline 55 & 61 & 62 & 58 & 62 & 58 & 58 & $5 \mathbf{a}$ & 58 & 3 & 4 & 0 & 4 \\
\hline 50 & 58 & 59 & 62 & 54 & 52 & 50 & 54 & 55 & 6 & 9 & 8 & -1 \\
\hline 45 & 53 & 58 & 53 & 57 & 48 & 48 & 49 & 50 & 5 & 10 & 4 & $\boldsymbol{T}$ \\
\hline 40 & 54 & 50 & 58 & 62 & 43 & 41 & 44 & 52 & 11 & 9 & 14 & 10 \\
\hline 35 & 44 & 48 & 56 & 60 & 36 & 35 & 49 & 40 & $\mathbf{8}$ & 23 & 7 & 20 \\
\hline \multirow[t]{2}{*}{30} & 45 & 47 & 55 & 52 & 33 & 37 & 51 & 47 & 12 & 10 & 4 & 5 \\
\hline & \multicolumn{8}{|c|}{ Diflerences amongst cohorts } & \multicolumn{4}{|c|}{$\begin{array}{c}\text { Mean Lag by Education } \\
\text { Group }\end{array}$} \\
\hline $\mathbf{y}-0=$ & -10 & -12 & -2 & $\mathbf{0}$ & -16 & -14 & -6 & -8 & 7.5 & 9.2 & 6.2 & 7.5 \\
\hline $30-55$ & -16 & -15 & -3 & -10 & -25 & -22 & -7 & -12 & & & & \\
\hline
\end{tabular}

\begin{tabular}{|c|c|c|c|c|c|c|c|c|c|c|c|c|}
\hline \multirow{2}{*}{$\frac{\text { Rduc }}{\text { AGE }}$} & \multicolumn{3}{|c|}{\begin{tabular}{|l|l|}
\multicolumn{2}{r}{ Hages } \\
12 & 16 \\
\end{tabular}} & $>16$ & \multicolumn{4}{|c|}{ Hours of All } & \multicolumn{4}{|c|}{ Lag } \\
\hline & \multicolumn{12}{|c|}{ Cohorts delineated by age in 1964.} \\
\hline 55 & \multirow{9}{*}{\multicolumn{4}{|c|}{$\begin{array}{c}\text { Wage data as } \\
\text { above }\end{array}$}} & 57 & 58 & 58 & 58 & 4 & 4 & 0 & 4 \\
\hline 50 & & & & & 52 & 52 & 54 & 54 & 6 & 7 & 8 & 0 \\
\hline 45 & & & & & 48 & 47 & 48 & 46 & 5 & 12 & 5 & 11 \\
\hline 40 & & & & & 42 & 41 & 42 & 43 & 12 & 9 & 16 & 29 \\
\hline 35 & & & & & jo & 44 & 49 & 42 & 6 & 4 & 7 & 18 \\
\hline \multirow[t]{2}{*}{ Jo } & & & & & 3 3 & 43 & 50 & 47 & 12 & 4 & 5 & 5 \\
\hline & & & & & \multicolumn{4}{|c|}{$\begin{array}{l}\text { Difterences } \\
\text { amongst cohorts }\end{array}$} & \multicolumn{4}{|c|}{$\begin{array}{c}\text { Mean Lag by Education } \\
\text { Group }\end{array}$} \\
\hline $\mathbf{x - O *}$ & & & & & -14 & -10 & -6 & $-B$ & \multirow[t]{2}{*}{7.5} & \multirow[t]{2}{*}{6.5} & \multirow[t]{2}{*}{6.8} & \multirow[t]{2}{*}{9.5} \\
\hline $30-55$ & & & & & -24 & -15 & -8 & -11 & & & & \\
\hline
\end{tabular}

- Note: $Y-O$ is the average difference between the three younger and the three older cohorts. 
LOG HOURLY WAGES by cohort oducation wasa then 12 yeare

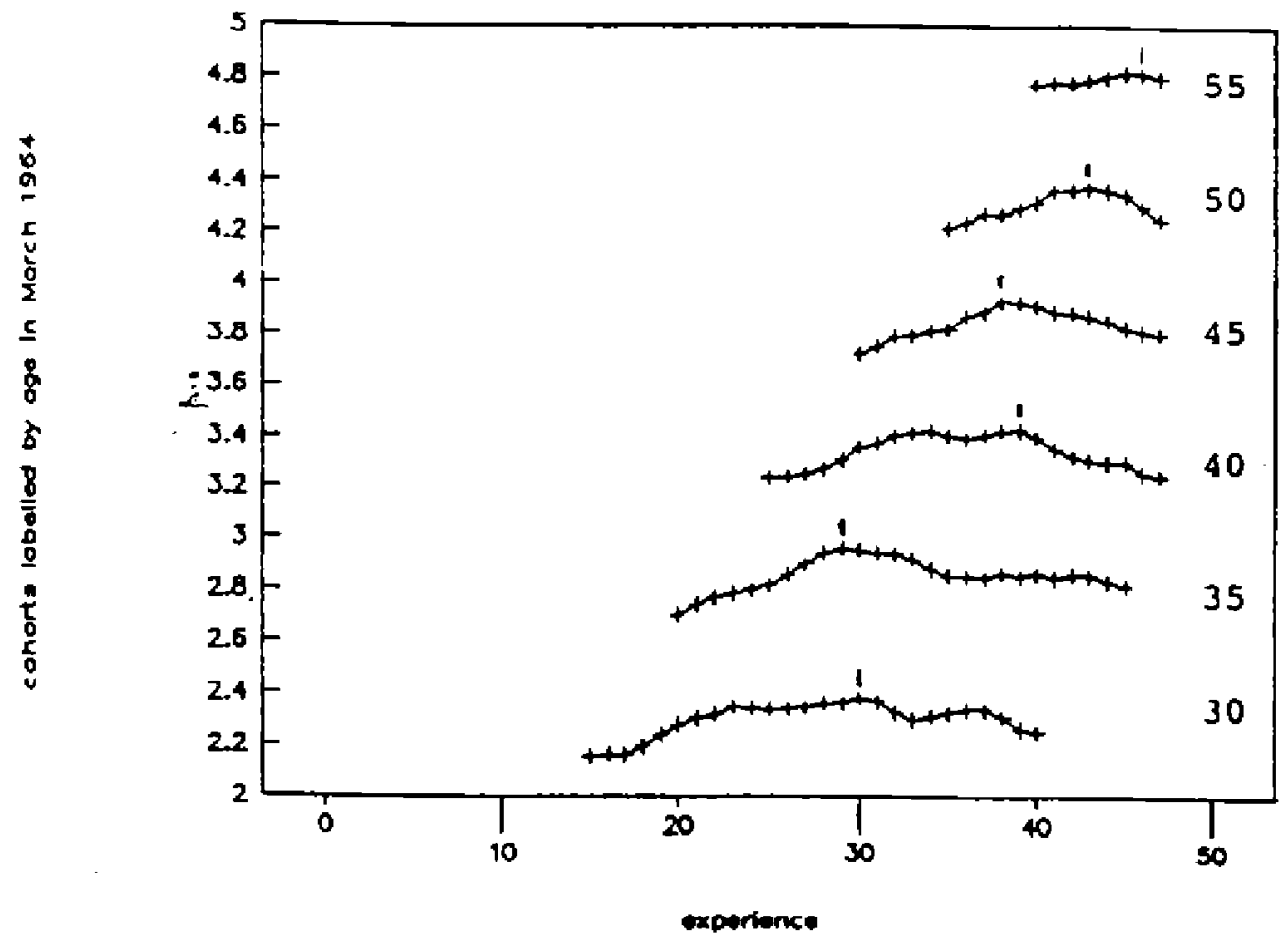

LOG HOURLY WAGES by cohort coucation equaling 12 yours

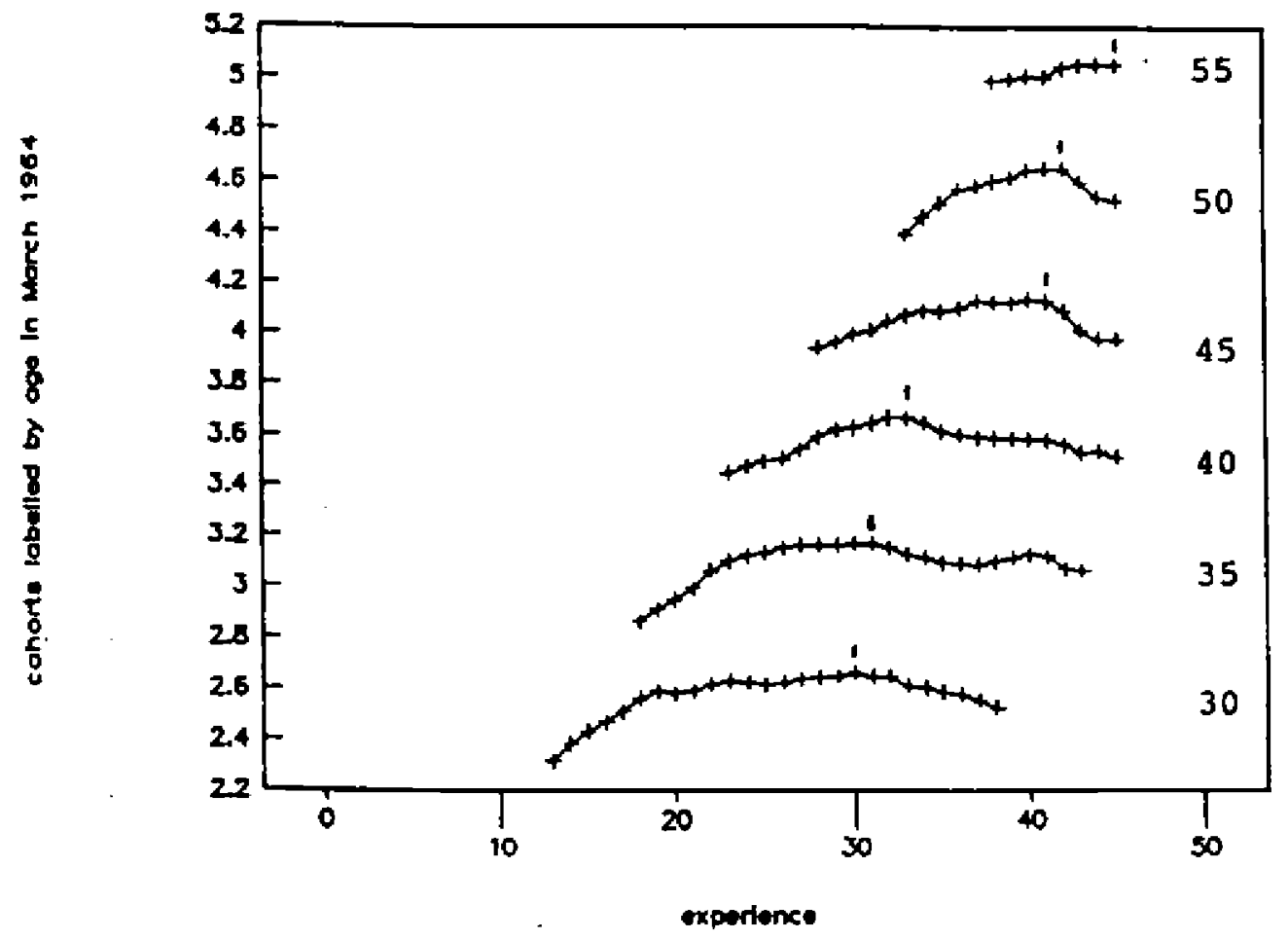

NOTE: The distances between cohorts are arbitrary 

HOURS OF EMPLOYED WORKERS by cohort
education tose thon 12 yours

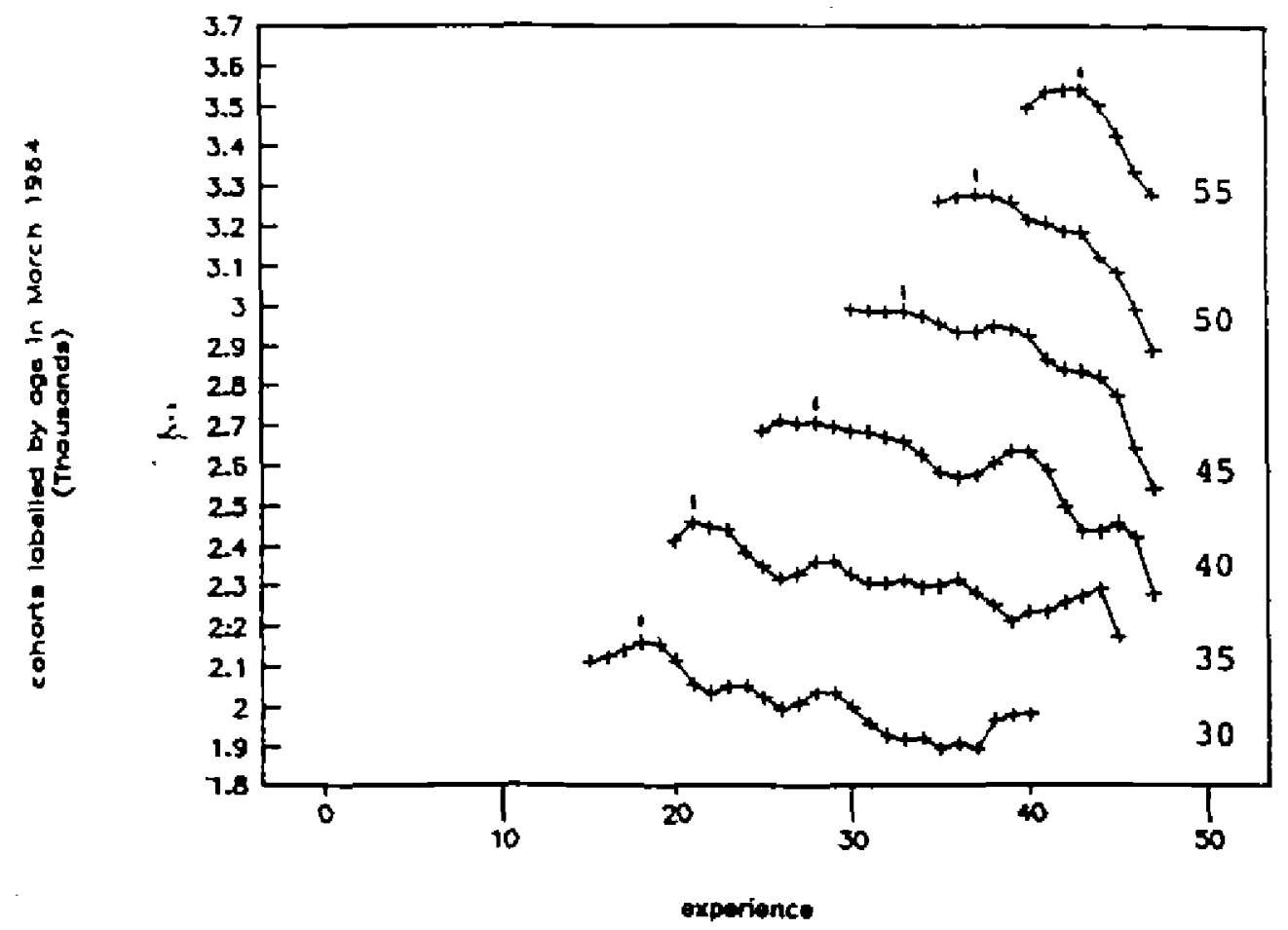

HOURS OF EMPLOYED WORKERS by cohort covedion equoting 12 years

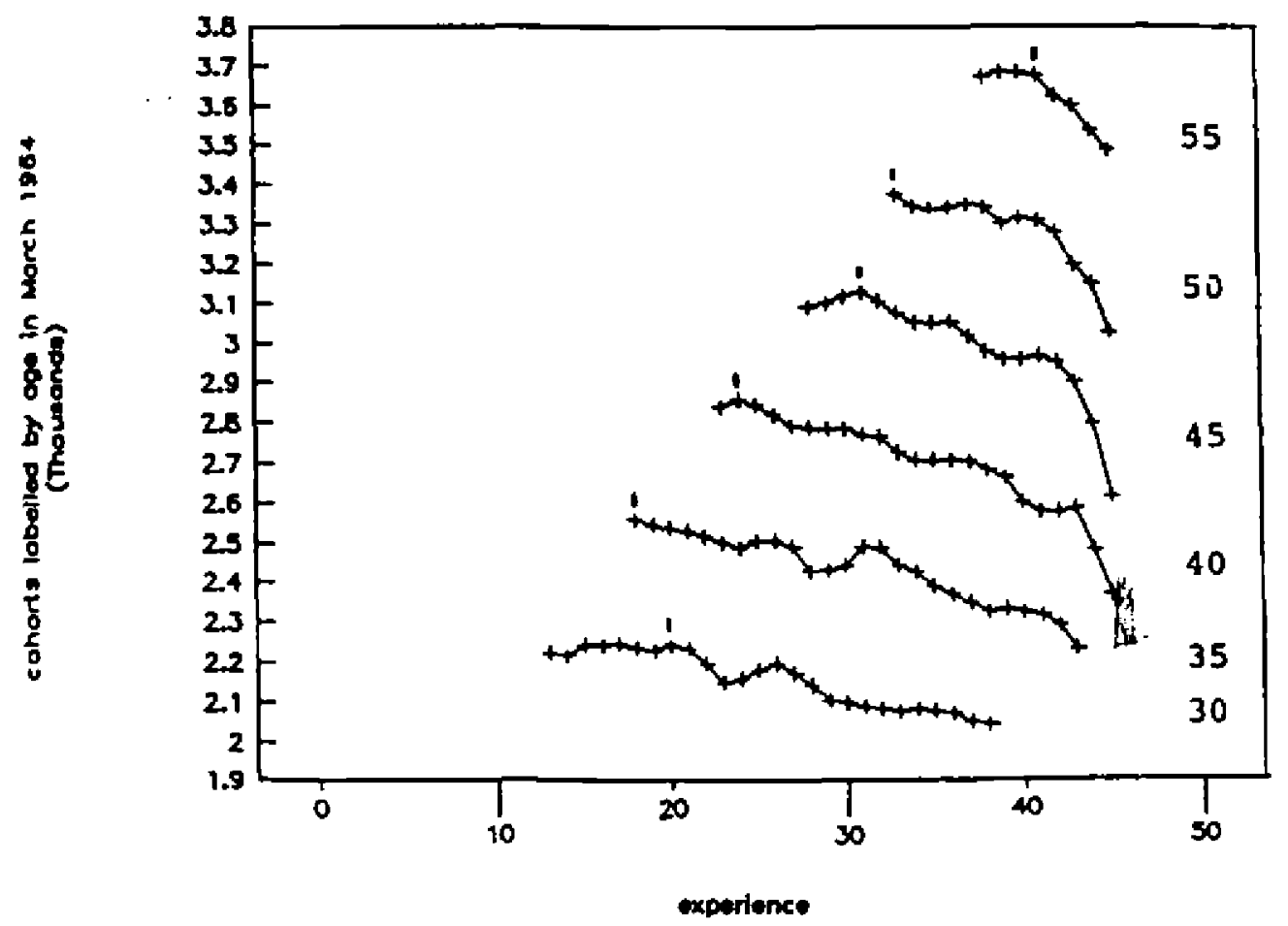

NOTE: The distances between cohorts are arbitrary 

HOURS OF EMPLD WORKERS by cross-section

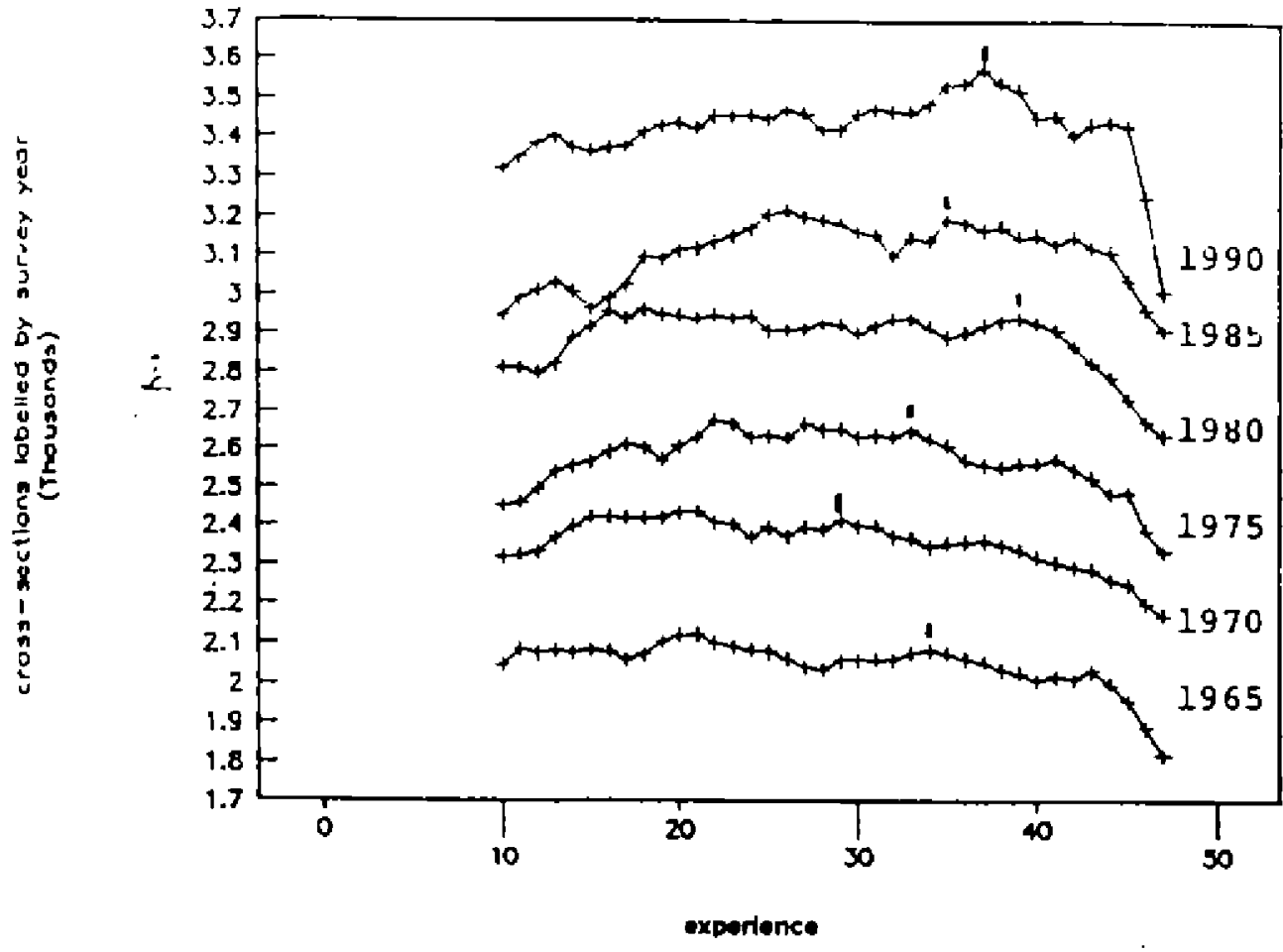

HOURS OF EMPLD WORKERS by cross-section educotion equaling 12 yeore

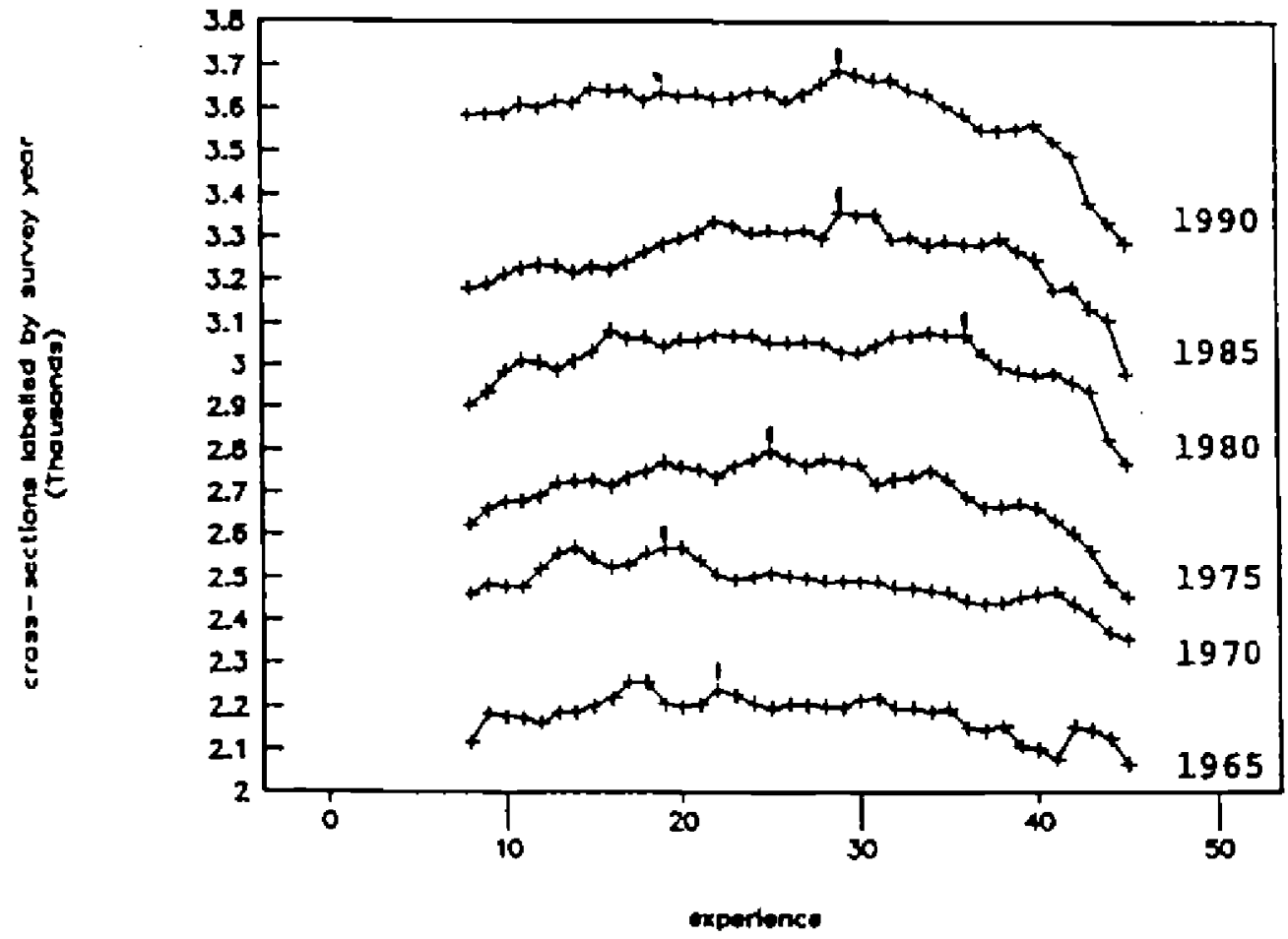

NOTE: The distances between cross-sections are arbitrary 
HOURS OF ALL WORKERS by cross-section

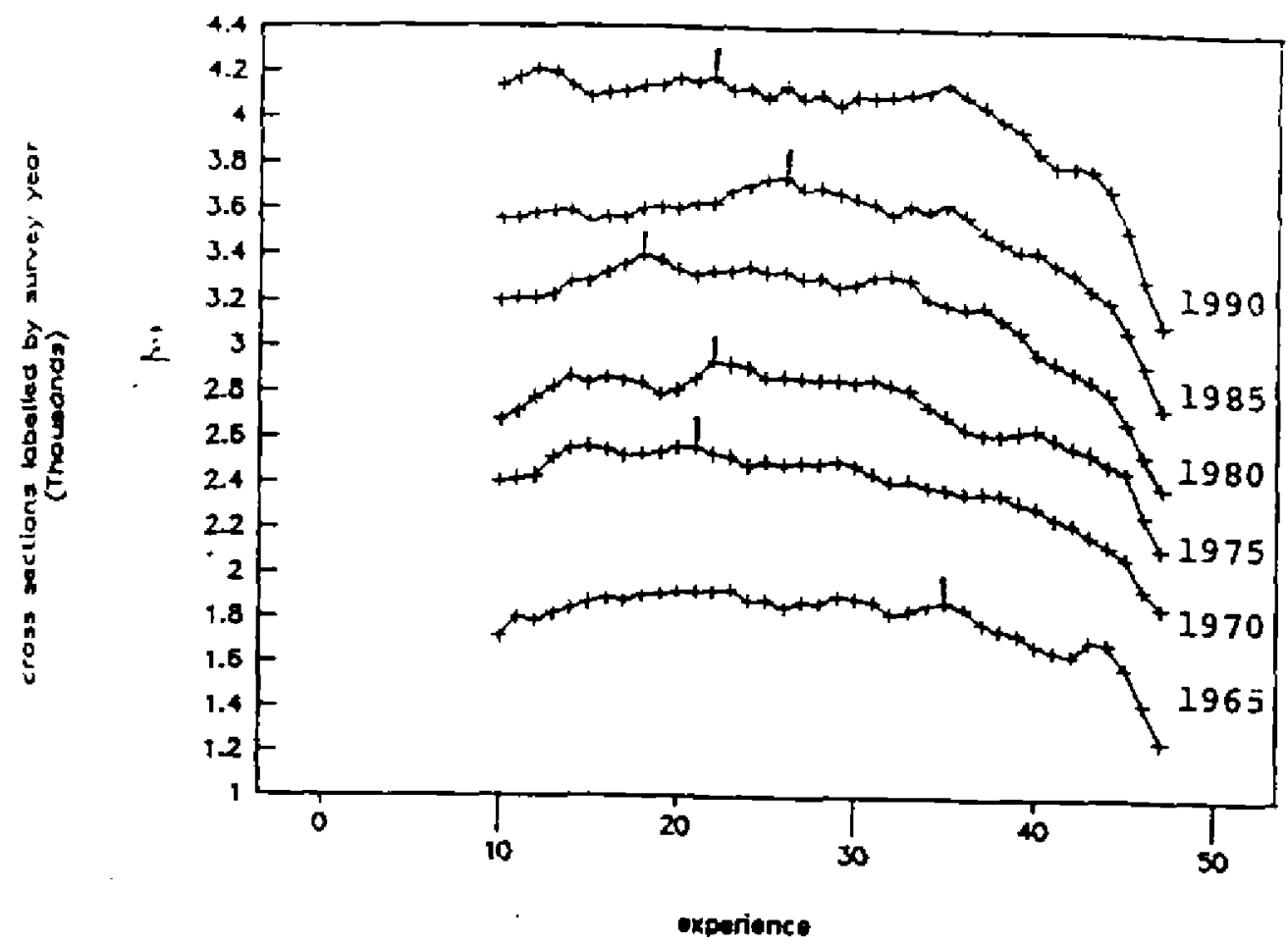

HOURS OF ALL WORKERS by cross-section caucation equaling 12 yoors

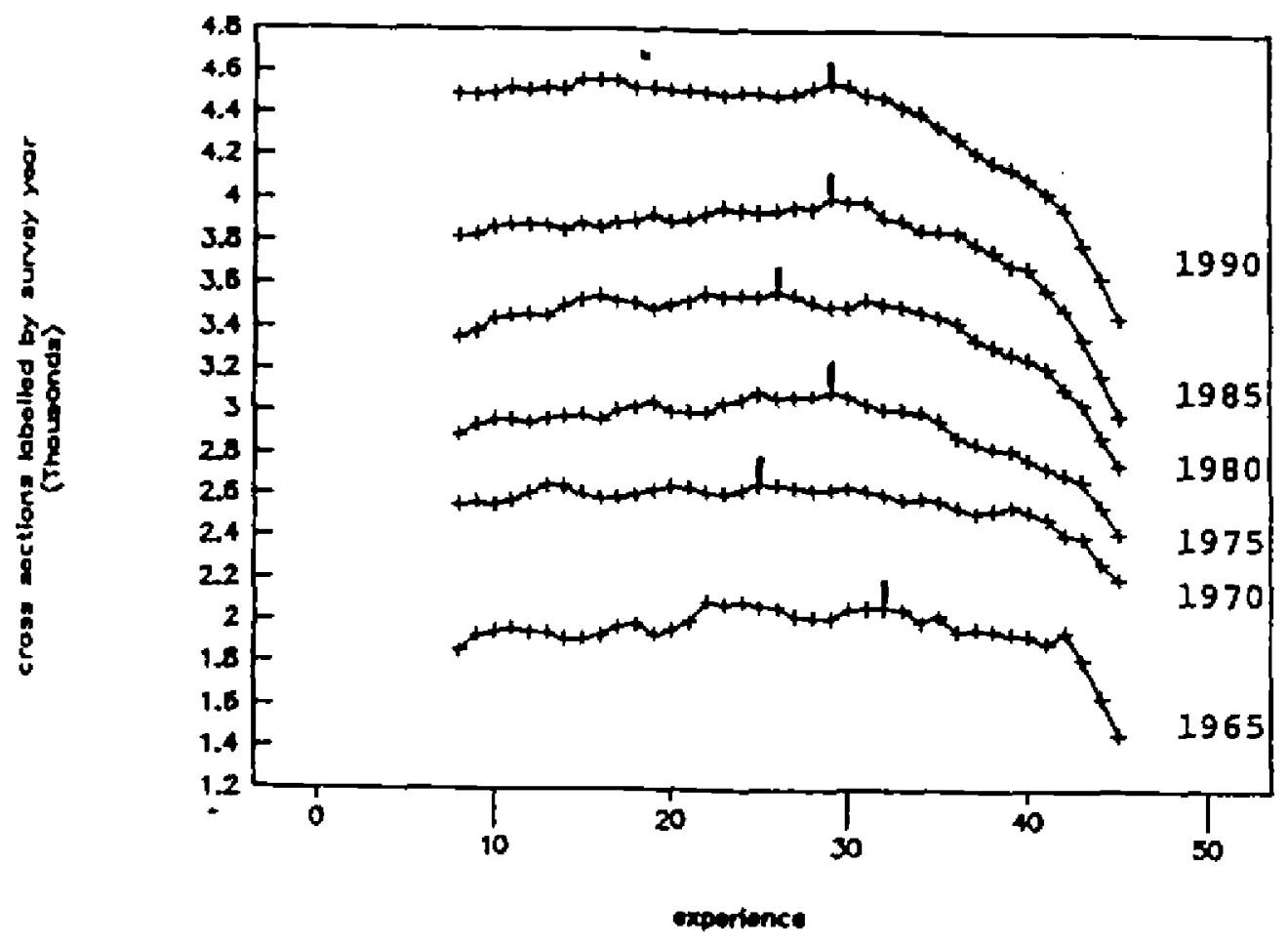

NOTE: The distances between cross-sectlons are arbitrary 